\title{
Biological activities of Annona montana Macfad extracts
}

\author{
Ana Isabel Giraldo-Rivera*1, Gloria Edith Guerrero-Álvarez ${ }^{1}$
}

Edited by

Juan Carlos Salcedo-Reyes

salcedo.juan@javeriana.edu.co

1. Universidad Tecnológica de Pereira, Escuela de Química, Facultad de Tecnología, Carrera 27 \#10-02, Pereira, Colombia. Post Code 660003.

*aigiraldo@utp.edu.co

Received: 06-07-2020

Accepted: 07-09-2021

Published online: 11-10-2021

Citation: Giraldo-Rivera AI, Guerrero-Álvarez GE. Biological activities of Annona montana Macfad extracts, Universitas Scientiarum, 26(3): 302-316, 2021.

doi: 10.11144/Javeriana.SC26-3.baoa

Funding: The development of scientific and technological capacities in biotechnology applied to health and agro-industry sectors in the Department of Risaralda, Colombia (BPIN

201200010050), which is funded by the CTeI Fund of the General Royalty System. WanaCol SAS for providing $A$. montana seeds

Electronic supplementary material: n.a.

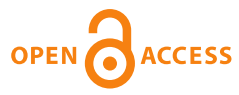

\begin{abstract}
Annona montana Macfad is a fruit species of the Annonaceae family. In this study, the phytochemical potential of A. montana seeds was investigated. Ethanol and hexane extracts from seeds were evaluated for cytotoxicity and insecticidal activity, phenolic content, and antioxidant capacity. The latter being related to free radical scavenging activity assay (DPPH) and ferric reducing power (FRAP). Exposing Artemia salina to both seed extract types reveled their high toxicity with a median lethal concentration (LC50) of $<10 \mu \mathrm{g} \mathrm{mL}^{-1}$. Further A. montana seed insecticidal activity was evaluated against Thrips tabaci $\mathrm{L}$., revealing that the most promising treatments were observed for a concentration of $100 \mathrm{mg} \mathrm{L}^{-1}$ in both extracts. The ethanol extract resulted in a mortality of $67.5 \%$ and the hexane extract in a $53.3 \%$ mortality. The ethanolic extract of A. montana seeds showed the highest total phenolic content: $297.38 \mathrm{mg} \mathrm{GAE} / 100 \mathrm{~g}$ of dried extract and $192.66 \mathrm{mg}$ TE/100 $\mathrm{g}$, and $385.46 \mathrm{mg}$ TE/100 $\mathrm{g}$ for DPPH and FRAP, respectively. The chemical characterization of both extracts by high performance liquid chromatography (HPLC) revealed the presence of acetogenins. The results obtained indicate that the A. montana extracts are a promising source of compounds with insecticidal activity.
\end{abstract}

Keywords: Annonaceae; antioxidant; cytotoxicity; DPPH, FRAP, insecticidal activity.

\section{Introduction}

The Annonaceae constitute a family with plesiomorphic traits, in fact it constitutes one the first flowering plant families included in the Ranalean complex. A total of 2400 trees and shrubs species in 130 genera are recognized within the Annonaceae. These are distributed throughout the tropical zones of America, Africa, Indochina, and Malaysia. From a chemical composition perspective, several studies carried out with the Annonaceae reveal that its species possess a wide spectrum of biological activities for pest control [1, 2, 3, 4].

Annona montana, also known as guanábana de monte or maroon soursop, is a tropical plant grown in South America and found in some parts of India. The tree is about $10 \mathrm{~m}$ in height and its yellow-green fruit, which is acidic, has several carpels and many light brown seeds and is highly valued for its striking aroma [2]. A. montana is used in traditional domestic medicine; infusions of its leaves serve to treat lice, influenza, and insomnia [3, 4].

The toxicity of A. montana fruit extracts have been evaluated in cell lines, whereby these were found to inhibit tumor cells growth in colon, breast, prostate, and lung cancers [5, 6]. Several studies have focused on the evaluation of $A$. montana insecticidal activity, namely evaluating seed extracts against insect pests such as Cabbage looper (Trichoplusia ni) and the Maize weevil (Sitophilus zeamais) in crops grains [7, 8]. Helicoverpa armigera, a polyphagous pest that damages the vegetative structures of soybean and corn have been exposed to A. montana extracts [9]. Furthermore, A. montana leaf and fruit extracts were evaluated against nymphs of Aphis 
craccivora [10] and Spodoptera frugiperda [11]. Furthermore, acetogenin isolates from leaves and twigs have also been assessed against Oncopeltus fasciatus [4] and disease vectors, such as Anopheles gambiae and Culex quinquefasciatus [12] with promising results.

The Annonaceae is the only family with plants producing acetogenins; metabolites that exhibit antitumor, antimalarial, anti-inflammatory, antimicrobial, immunosuppressant, and pesticidal properties. Acetogenins are central in the production of benzylisoquinoline alkaloids $[13,14]$. There are no reports of the insecticidal activity of A. montana against Thrips tabaci. T. tabaci is an important pest found worldwide, infesting more than 300 species of plants and is one of the main plagues of onion crops $[15,16,17]$.

Considering the great potential of Annonaceae extracts, we conducted bioprospection assays with A. montana seeds. Thus, we evaluated different activities of polar and non-polar seed extracts. Cytotoxicity against Artemia salina was first assessed as a potential predictor assay for insecticidal and biological screening for potential bioactive drugs. Next, we studied the insecticidal effect against $T$. tabaci L. and the antioxidant activity value of the extracts, using the 1,1-diphenyl2-picrylhydrazyl (DPPH) scavenging method and the ferric reducing power method. Further, acetogenin-like compounds were identified and total phenolic content (TPC) of the extracts were determined.

\section{Materials and Methods}

\subsection{Annona montana seeds}

A. montana seeds were gathered in jurisdiction of Caicedonia, Valle del Cauca, Colombia. The taxonomic identification of the plant took place in the herbarium at Universidad del Quindío with voucher number 38331. In the preparation of the extract, the washing of the seeds with TEGO 51 soap and drying processes at $37^{\circ} \mathrm{C}$. Finally, a mill IKA MF 10 BASIC was used to obtain a fine powder stored under refrigeration [18].

\subsection{Extract preparation}

To obtain the polar extract of A. montana seeds, passive maceration was carried out at room temperature. The sample was subjected to regular agitation for one week using ethanol as the solvent, in a sample-solvent ratio of 1:4 (w/v) and filtration under vacuum. The non-polar extract was obtained using the Soxhlet extraction technique employing hexane as the solvent, in a sample to solvent ratio of 1:5 (v/w), for 24 hours [18]. The solvent was rotary evaporated at low pressure, concentrated with nitrogen gas, and kept at $4{ }^{\circ} \mathrm{C}$.

\subsection{Cytotoxic activities against Artemia salina}

The cytotoxic activity analysis was made with the methodology described by McLaughlin [19, 20] with some modifications. Artemia salina eggs were hatched in a $3.7 \%$ artificial seawater solution, and then incubated at $30^{\circ} \mathrm{C}$ for 48 hours. A. montana seed extracts of different concentrations $\left(0.5 \mathrm{mg} \mathrm{L}^{-1}, 1 \mathrm{mg} \mathrm{L}^{-1}, 3 \mathrm{mg} \mathrm{L}^{-1}, 5 \mathrm{mg} \mathrm{L}^{-1}\right.$ and $\left.10 \mathrm{mg} \mathrm{L}^{-1}\right)$ were then evaluated, adding $10 \mathrm{~A}$. salina nauplii to each experimental unit. Two controls were prepared; the first with artificial seawater solution, and the second with ethanol solution. All tests were performed three times. After 24 hours the numbers of alive and motionless A. salina larvae were counted.

Universitas Scientiarum Vol. 26(3):302-316 http://ciencias.javeriana.edu.co/investigacion/universitas-scientiarum 


\subsection{Evaluation of the insecticidal activity against Thrips tabaci}

Morphological identification of T. tabaci: Thrips larvae were taken from onion crops in vereda La Florida, municipality of Pereira, Risaralda, Colombia. Infested leaves were plucked, stored hermetically in plastic bags, and carried to laboratory for analysis. In the laboratory, larvae were separated from the leaves and placed in a Petri box containing a solution of ethanol (70\%) [21]. Larvae were identified with the help of a microscope, following the taxonomic keys proposed in previous studies [22].

\subsection{Median lethal concentration (CL50) assessment}

The biocidal activity of the extract was evaluated in the farm where thrips larvae were sampled. Bioassays were conducted at room temperature $\left((21 \pm 1){ }^{\circ} \mathrm{C}\right)$; at a relative humidity $(\mathrm{RH})$ of $(50 \pm 10) \%$. T. tabaci larvae were net-collected from onion crops, following the methodology implemented in previous studies [23]. A randomized experimental design with eight treatments and six repetitions was followed. The extracts were diluted with dimethyl sulfoxide (DMSO) and distilled water to obtain different concentrations $\left(10 \mathrm{mg} \mathrm{L}^{-1}, 50 \mathrm{mg} \mathrm{L}^{-1}\right.$ and $\left.100 \mathrm{mg} \mathrm{L}^{-1}\right)$. These doses were tested in independent trials and with the same review and control treatment. Two controls were employed, a blank containing the same amount of dimethyl sulfoxide (DMSO) was used to dissolve the extracts and Lorsban 4EC insecticide, which belongs to the chlorpyrifos family.

\subsection{Determination of total phenolic content (TPC)}

A. montana extracts were determined following the Folin Ciocalteu method, as previously reported [24]. Briefly, $50 \mu \mathrm{L}$ of the extract $\left(12500 \mathrm{mg} \mathrm{L}^{-1}\right)$ were mixed with $120 \mu \mathrm{L}$ of water with $50 \mu \mathrm{L}$ of the Folin-Ciocalteu reagent were dissolved in water (1:20) and $80 \mu \mathrm{L}$ of $\mathrm{KOH}(0.175 \mathrm{M})$. Absorbance was measured at $760 \mathrm{~nm}$. A calibration curve was plotted using gallic acid as the reference standard with a concentration range of $5 \mathrm{mg} \mathrm{L}^{-1}$ to $80 \mathrm{mg} \mathrm{L}^{-1}$. The results were expressed in milligrams of gallic acid equivalents per $100 \mathrm{~g}$ of sample (mg GAE/100 $\mathrm{g}$ of extract).

\subsection{DPPH free radical scavenging activity assay}

DPPH was performed following a method previously described [25]. Briefly, $10 \mu \mathrm{L}$ of the extract $\left(25000 \mathrm{mg} \mathrm{L}^{-1}\right)$ were mixed with $200 \mu \mathrm{L}$ of DPPH-ethanol solution at $50.7 \mu \mathrm{M}\left(20 \mathrm{mg} \mathrm{L}^{-1}\right)$. Absorbance was measured at $517 \mathrm{~nm}$, and a calibration curve was plotted using Trolox as the reference standard with a concentration range of $10 \mu \mathrm{M}$ to $400 \mu \mathrm{M}$. Results were expressed in milligrams of Trolox equivalents per $100 \mathrm{~g}$ of extract (mg TE/100 g extract).

\subsection{Ferric reducing antioxidant power FRAP}

This analysis was performed according to a previously proposed method [26]. FRAP reagent was prepared mixing a $300 \mathrm{mM}$ acetate buffer solution (pH 3.6) with $10 \mathrm{mM}$ TPTZ, $40 \mathrm{mM} \mathrm{HCl}$, and $20 \mathrm{mM} \mathrm{FeCl} 3$ solution (ratio, 10:1:1). Subsequently, $150 \mu \mathrm{L}$ of the FRAP reagent were added to $20 \mu \mathrm{L}$ of extract $\left(12500 \mathrm{mg} \mathrm{L}^{-1}\right)$. The reaction mixture was incubated at $37^{\circ} \mathrm{C}$ for $30 \mathrm{~min}$, and the absorbance was measured at $593 \mathrm{~nm}$. A calibration curve was plotted using Trolox as the reference standard with a concentration range of $20 \mathrm{mg} \mathrm{L}^{-1}$ to $100 \mathrm{mg} \mathrm{L}^{-1}$. Results were expressed in milligrams of Trolox equivalents per $100 \mathrm{~g}$ of extract (mg TE/100 g extract). 


\subsection{Chemical characterization}

For the analysis of the acetogenins, A. montana crude extracts were diluted in a chloroform - water solution in a 1:1 ratio and a liquid-liquid extraction was carried out following the methodology described elsewhere [27].

High performance liquid chromatography (HPLC) analysis: This analysis was made in a Jasco 2000 plus chromatograph, equipped with (i) a quaternary gradient pump (PU-2089 Plus), (ii) an intelligent autosampler (AS-2059Plus), (iii) a column oven (CO-2065 Plus), and (iv) an intelligent diode array detector (MD-2015 Plus). For fraction analysis, an ODS2 Spherisil reverse phase column $(250 \mathrm{~mm} \times 4.6 \mathrm{~mm}$ i.d, $5.0 \mu \mathrm{m})$ and a Spherisil pre-column $(5.0 \mathrm{~mm} \times 4.6 \mathrm{~mm}$ i.d, $5.0 \mu \mathrm{m}$ ) were used (CAPITAL HPLC, Broxburn, United Kingdom). An isocratic method, with a mobile phase of water (A) and acetonitrile (B) in a 30:70 ratio, at a rate of $1 \mathrm{~mL} \mathrm{~min}^{-1}$ with a running time of $50 \mathrm{~min}$, was employed. A volume of $20 \mu \mathrm{L}$ of sample at $100 \mu \mathrm{g} \mathrm{mL}^{-1}$ was injected. Acetogenins were identified using the UV-Vis spectrum of the Bullatacina standard [18].

\section{Data analysis}

Cytotoxic and biocidal activity results were expressed as mean $\pm \mathrm{SD}$. An analysis of variance (ANOVA) was used to test for the difference of means; Tukey's test, at a $5 \%$ significance level, was employed for the toxicity test with Artemia, and a Hoteling test with Bonferroni corrected level of $P<0.05$ was used for insecticidal activity. Mean lethal concentration (LC50) was determined using Probi analysis. Results were obtained with the help of the statistical software Infostat version 2008.

\section{Results}

Cytotoxic activity against $A$. salina: Table 1 shows cytotoxicity results, all of the A. montana seed extract doses exerted larvicidal activity on A. salina, revealing statistical difference between treatments and controls. The dose of $10 \mathrm{mg} \mathrm{L}^{-1}$ led to the highest percentage of A. salina mortality (> $80 \%$ ). As revealed by A. salina experiments, the mean lethal concentration (LC50), calculated after $24 \mathrm{~h}$, for the non-polar extract was $3.58 \mathrm{mg} \mathrm{L}^{-1}$ and for the polar extract was $3.22 \mathrm{mg} \mathrm{L}^{-1}$. This supports previous findings that both extract types were highly active [23, 27].

\subsection{Insecticide activity against thrips}

Morphological identification of the thrips from onion crops revealed that the insects belong to the species T. tabaci, diagnostic features are shown in Figure 1, and entail: three thoracic segments (Figure 1A), three pairs of thoracic legs (Figure 1B), ten abdominal segments (Figure 1C), and one antenna divided in seven sectors (Figure 1D); there were no projecting parts. This description agrees with that reported in the literature [28].

In the test against $T$. tabaci larvae, all doses of the polar and non-polar A. montana seed extracts had a biocidal effect on the larvae (Figure 2). The level of response depended on extract concentration. No significant differences were noted between the treatments with polar and non-polar extracts, but there were significant differences between extracts and control.

The highest percentage of mortality was reached working at an extract (polar and non-polar) concentration of $100 \mathrm{mg} \mathrm{L}^{-1}$; at 24 hours, the polar extract led to a mortality of $67.5 \%$ and the non-polar extract to a mortality of $53.3 \%$. The control did not exert mortality and the Lorsban 
Table 1. Mortality of Artemia salina larvae upon 24-h exposure to different concentrations of (A) polar extract and (B) non-polar extracts of Annona montana seeds. Values followed by different letters indicate differences between treatments according to a Tukey test at a $5 \%$ probability level.

\begin{tabular}{cccc}
\hline Extracts & Concentration $\left(\mathrm{mg} \mathrm{L}^{-1}\right)$ & Mortality (\%) & Median lethal concentration (LC50) \\
\hline \multirow{4}{*}{ Ethanol } & 0.5 & $34.7 \pm 7.5^{a}$ & \\
& 1 & $56.45 \pm 9.12^{b}$ & $3.2 \mathrm{mg} \mathrm{L}^{-1}$ \\
3 & $82.30 \pm 3.25^{b}$ & \\
& 5 & $86.10 \pm 2.40^{b}$ & $3.58 \mathrm{mg} \mathrm{L}^{-1}$ \\
Hexane & 10 & $94.40 \pm 7.92^{b}$ & \\
& 0.5 & $22.30 \pm 0.71^{a}$ & - \\
\hline Negative control & 1 & $34.45 \pm 4.88^{a}$ & - \\
\hline Positive control & 5 & $37.00 \pm 8.49^{a}$ & \\
\hline
\end{tabular}

4EC insecticide control led to a percentage of mortality ( $78 \%$ ) at a concentration of $96 \mathrm{mg} \mathrm{L}^{-1}$. The median lethal concentration (LC50) for the polar extract was $68 \mathrm{mg} \mathrm{L}^{-1}$, and for the hexane extract it was $97.5 \mathrm{mg} \mathrm{L}^{-1}$. These results reaffirm the fact that the highest lethality, found in the present study, corresponds to the ethanolic extract. Thus, these values show that the extracts of $A$. montana can control T. tabaci.
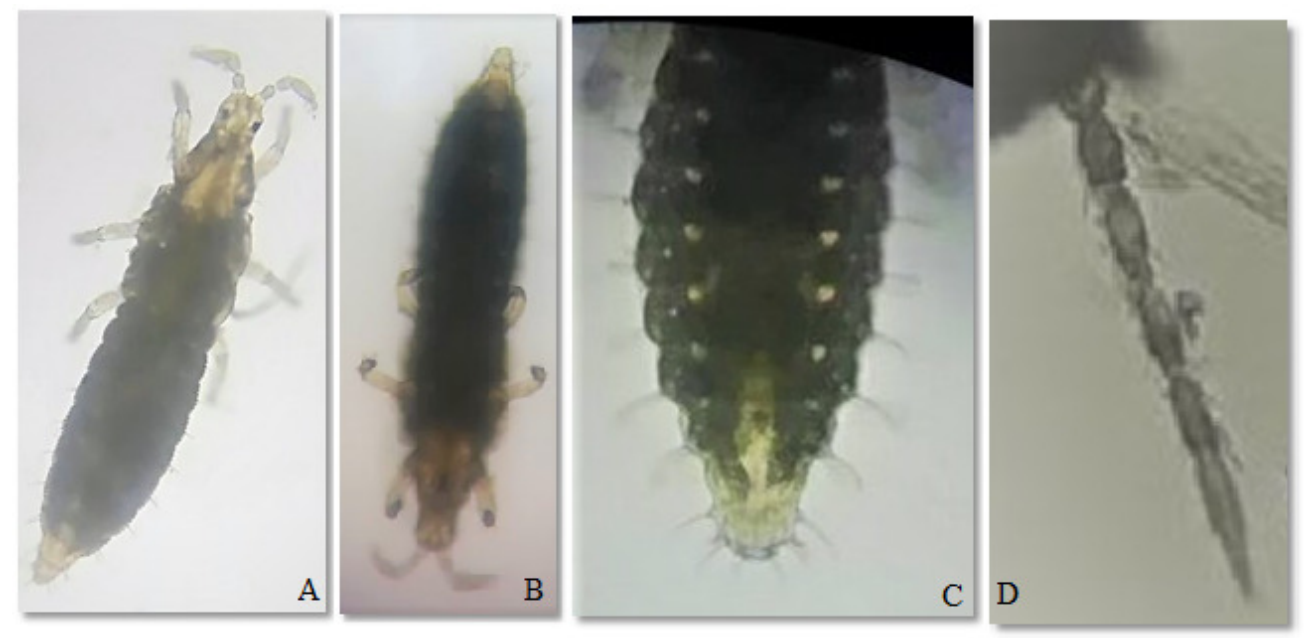

Figure 1. External characters of Thrips tabaci in its larval stage II (A) Body, (B) Legs, (C) Abdominal segments, and (D) Antenna. 


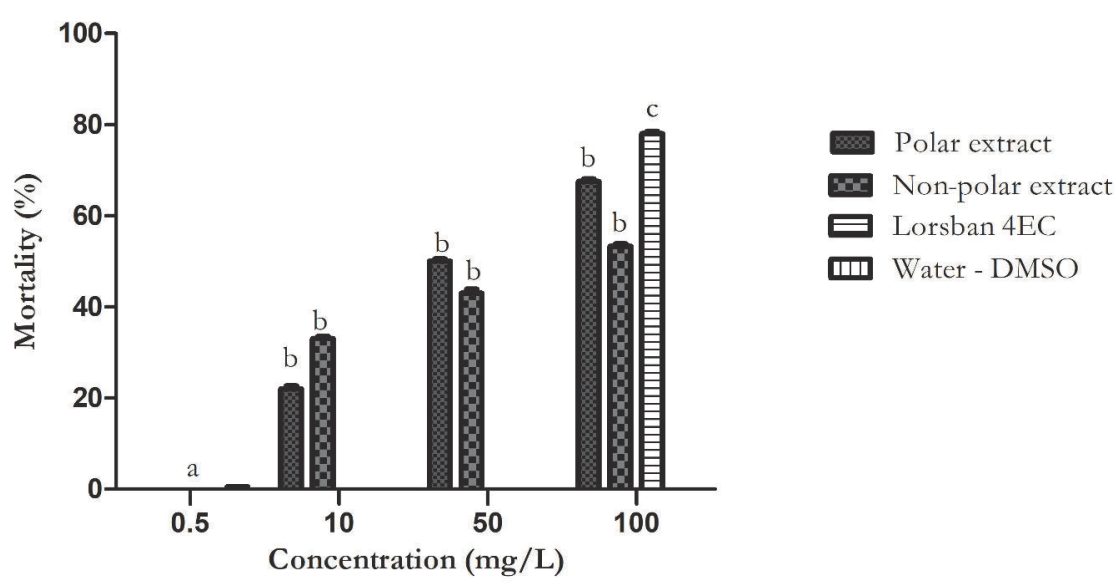

Figure 2. Mortality of Thrips tabaci larvae exposed to different concentrations of (A) polar extract (B) and non-polar extract of Annona montana seeds for $24 \mathrm{~h}$. Bars sharing a letter did not differ significantly according to a Tukey test at a $5 \%$ probability level.

\subsection{Total phenolic content and antioxidant activity}

Table 2 shows the results of TPC determined using the Folin-Ciocalteu method and antioxidant capacity by the FRAP and DPPH methods. The extracts revealed TPC mean values between $220 \mathrm{mg}$ to $300 \mathrm{mg}$ GAE/100 $\mathrm{g}$ of extract, agreeing with values observed by other authors [29]. The ethanol extract showed the highest total phenolic content. As per $T$-test, no significant differences were noted in the TPCs. The extracts showed antioxidant activity in a range of $150 \mathrm{mg} \mathrm{TE} / 100 \mathrm{~g}$ to $400 \mathrm{mg} \mathrm{TE} / 100 \mathrm{~g}$ of extract. The ethanol extract had the highest antioxidant activity for both methods. However, using the FRAP method, extracts showed increased antioxidant activity. Based on the results of ANOVA at a significance level of $5 \%$, there were significant differences between the antioxidant activities of extracts. Furthermore, TPC revealed linear correlations between antioxidant activity assessed and method: FRAP $(r=0.62)$ and DPPH $(r=0.57)$.

\subsection{Acetogenin characterization}

A total of 25 acetogenin-like compounds were recognized (Figure 3) via high resolution liquid chromatography (HPLC) on seed extracts, based on their UV-Vis spectra with absorbance maxima between $200 \mathrm{~nm}$ and $220 \mathrm{~nm}$ [27]. Of the 25 compounds, 12 were from the polar extract, while the remaining 13 were from the non-polar extract. This could be indicative of the presence of a wide range of acetogenin compounds. These findings may help explain their difference in biological

Table 2. Total phenolic content and antioxidant activity as assessed using the DPPH and FRAP methods of the ethanolic and hexane extracts of Annona montana seeds.

\begin{tabular}{lccc}
\hline Extracts & $\begin{array}{c}\text { Total phenolic content } \\
(\mathrm{mg} \text { GAE/100 g of extract) }\end{array}$ & $\begin{array}{c}\text { FRAP method } \\
\text { (mg TE/100 g of extract) }\end{array}$ & $\begin{array}{c}\text { DPPH method } \\
\text { (mg TE/100 g of extract) }\end{array}$ \\
\hline Ethanol & $297.38 \pm 16.23^{b}$ & $385.46 \pm 13.57^{c}$ & $192.66 \pm 27.52^{a}$ \\
Hexane & $220.63 \pm 20.74^{b}$ & $360.05 \pm 16.15^{c}$ & $155.49 \pm 31.75^{a}$ \\
\hline
\end{tabular}




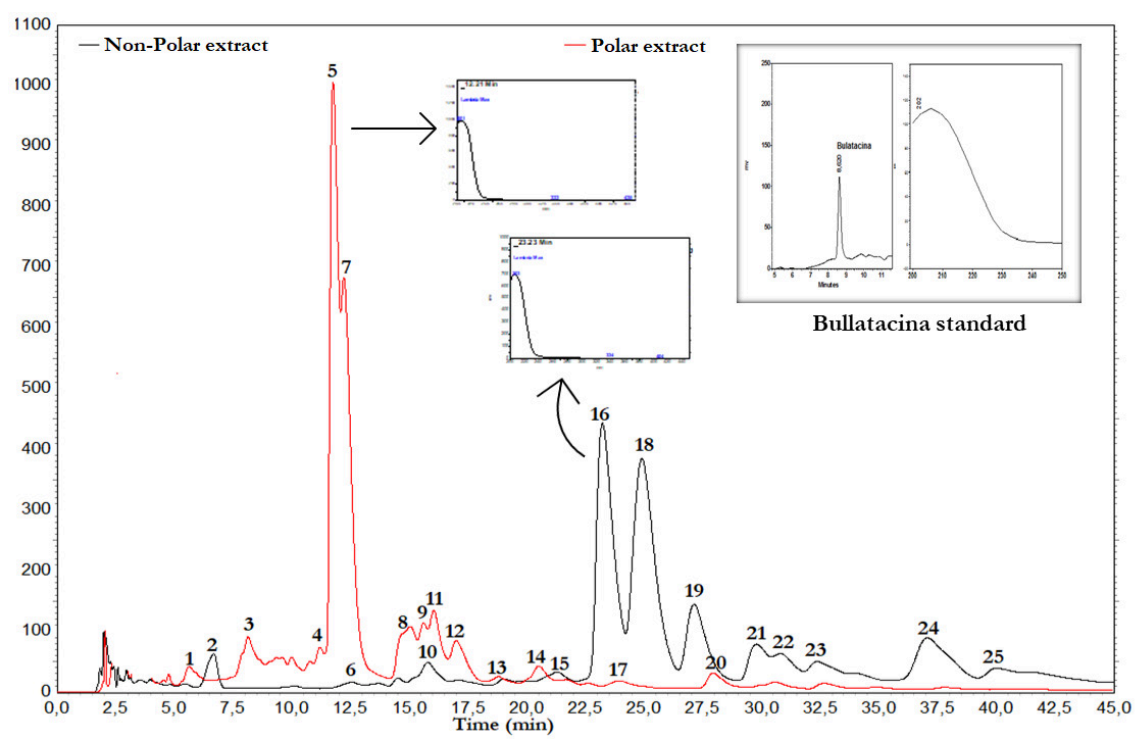

Figure 3. Chromatographic profile of acetogenins compounds check-up to polar and non-polar extracts of Annona montana seeds.

activity; it has been reported that the structural characteristics of an acetgonin determine its type of bioactivity as well as its degree of lethality [30-32]. The difference in the composition could explain the higher insecticidal activity of the polar extract.

\section{Discussion}

Acetogenins are one of the main substances present in seeds of the Annonaceae family [13, 14]. According to previous studies, A. montana seeds contain different types of acetogenins with toxic, insecticidal, and feeding dissuasive effects $[4,10]$. Reported acerogenins include, squamocin and molvizarin (bis-tetrahydrofuran acetogenins); montalicins A-E; cis-annoreticuins, montalicins F, $\mathrm{I}$, and $\mathrm{J}$, that are mono-tetrahydrofuran [4, 30,33]; linear acetogenins [31]; and acetogenins with a tetrahydropyran ring [34].

Insecticidal activity was observed after $24 \mathrm{~h}$ of treatment, thrips larvae were motionless and had a yellowish color; these effects can be related acetogenin compounds present in the studied seed extracts. These compounds inhibited the mitochondrial complex I (NADH: ubiquinone oxidoreductase), either by contact or ingestion, blocking sodium channels and inducing paralysis followed by death [35]. It has also been reported that other acetogenins present in A. montana have insecticidal and deterrent effects [30]. Furthermore, the variability observed in acetogenin modes of action may depend on the different functional groups present in these metabolites [36].

Other important types of compounds reported in A. montana seeds correspond to isoquinoline alkaloids; these compounds affect acetylcholinesterase or sodium channels [37]. Some phenolic compounds are toxic to mitochondria because of their broad-spectrum electron transport chain inhibition. Terpenoids are another type of compounds with insecticidal activity, their effects on insects range from repellency, exerted as a deterrent to feeding and oviposition, to interference with growth and development and, ultimately, acute toxicity [38]. 
When assessing seed extract antioxidant activity, two methods were implemented. This was necessary because tow response mechanisms were known to involved, and it was impossible to determine their activity using a single method. The FRAP method measures the ability of the compounds to reduce Fe III to Fe II, forming a blue complex with 2,4,6-Tris(2-pyridyl)-s-triazine (TPTZ). Whereas the DPPH method involves the reduction of the DPPH radical, which provides a rate to estimate the ability of a compound to capture radicals [39].

There are no previous reports of antioxidant activity in A. montana seed extracts; however, extracts of A. montana fruit flesh, with IC50 less than $100 \mathrm{ppm}$, have been characterized as rich in antioxidants [40]. TPC was not found to have a strong linear correlation with the antioxidant activity assessed using both methods. This is possibly due to antioxidant activity mostly attributed to phenolic-type compounds [41, 42]. These compounds have been reported in fruit flesh and leaves of other species within the Annonaceae [41, 43, 44].

Finally, Ethanolic and Hexane extracts of $A$. montana could make a real contribution to the task of controlling thrips populations; it is necessary to continue the field assays to establish their degree of incidence. This considers that in different countries biodegradable products, botanical insecticides, and biopesticides have been successfully used to get reductions of the pest population of the order of $58.14 \%[17,45,46]$ and chemical characterization studies should be expanded and carried out to allow greater safety of the compounds present.

\section{Conclusion}

In this work, we have expanded the bioprospecting of $A$. montana seed polar and non-polar extracts by studying their cytotoxic, insecticidal and antioxidant activities. When Thrips were exposed to these extracts, mortality rates were high at low extract concentrations. Thus, $A$. montana seed extracts have great potential as bio insect pest controllers. Although acetogenins and phenolic compounds were identified within the extracts, their chemical characterization should be conducted.

\section{Acknowledgements}

This research was supported by the ongoing initiative for the development of scientific and technological capacities in biotechnology applied to health and agro-industry sectors in the Department of Risaralda, Colombia (BPIN 201200010050), which is funded by the CTeI Fund of the General Royalty System. A. I. Giraldo was supported with a young researcher stipend from Sistema Universitario del Eje Cafetero (SUEJE). The authors thank WanaCol SAS for providing A. montana seeds and L. G. Ríos, M.Sc. for revising this manuscript.

\section{Conflict of interest}

The authors declare that there are no conflicts of interest.

\section{References}

[1] Gonzales-Esquinca AR, De la cruz-Chacón I, Castro-Moreno M, Orozco-Castillo JA, RileySaldaña CA. Alkaloids and Acetogenins in Annonaceae Development: Biological Considerations, Revista Brasileira de Fruticultura, 36(esp1): 1-16, 2014. 
doi: 10.1590/S0100-29452014000500001

[2] Lim. TK. Edible Medicinal and Non-Medicinal Plants: Fruits, Springer, 221-226, 2012.

[3] Barbalho S, Goulart R, Farinazzi-Machado FM, De Souza M, Do Santos Bueno PC, Guiguer E, Araújo A, Groppo M. Annona sp: Plants with Multiple Applications as Alternative Medicine - A Review, Current Bioactive Compounds, 8(3): 277-286, 2012.

doi: $10.2174 / 157340712802762500$

[4] Colom OA, Barrachina I, Mingol IA, Gonzalez MC, Sanz PM, Neske A, Bardon A. Toxic effects of annonaceous acetogenins on Oncopeltus fasciatus, Journal of Pest Science, 81(2): $85-9,2008$.

doi: 10.1007/s10340-007-0189-2

[5] Chávez PI, Sánchez LA, González FA, Rodríguez JL, Axelrod F. Cytotoxicity correlations of Puerto Rican plants using a simplified brine shrimp lethality screening procedure, International Journal of Pharmacognosy, 35(4): 222-226, 1997.

doi: 0925-1618/97/3504-0222\$12.00

[6] Bailon-Moscoso N, Romero JC, Ramirez MI, Ojeda K, Granda G, Ratoviski EA, OstroskyWegman P. Cytotoxic and genotoxic effects of extracts from Annona montana M. fruit, Food and Agricultural Immunology, 6: 17, 2016.

doi: 10.1080/09540105.2016.1148121

[7] Ribeiro LP, Akhtar Y, Vendramim JD, Isman MB. Comparative bioactivity of selected seed extracts from Brazilian Annona species and an acetogenin-based commercial bioinsecticide against Trichoplusia ni and Myzus persicae, Crop Protection, 62: 100-6, 2014.

doi: 10.1016/j.cropro.2014.04.013

[8] Ribeiro LP, Vendramim JD, Andrade MS, Bicalho KU, Silva MFGF, Vieira PC, Fernandes JB. Tropical Plant Extracts as Source of Graint-Protectant Compounds Againt Sitophilus zeamais Motschulsky (Coleoptera: Curculionidae), Neotropical Entomology, 43: 470-482, 2014.

doi: 10.1007/s13744-014-0233-x

[9] Souza CM, Baldin ELL, Ribeiro LP, Silva IF, Morando R, Bicalho KU, Vendramim JD, Fernandes JB. Lethal and growth inhibitory activities of Neotropical Annonaceae-derived extracts, commercial formulation, and an isolated acetogenin against Helicoverpa armigera, Jorunal of Pest Science, 90(2): 701-9, 2017.

doi: 10.1007/s10340-016-0817-9

[10] Da Silva Bandeira HF, Silva AC, Trassato LB, Strucker A, De Jesus Vieira A. Bioactivity of Annona montana Macfad extracts on the black cowpea aphid (Aphis craccivora Koch), Revista Brasileirade Ciências Agrárias, 12(11): 41-6, 2017.

doi: 10.5039/agraria.v12i1a5419 
[11] Di Toto L, Colom O, Popich S, Neske A, Bardón A. Antifeedant, and toxic effects of acetogenins from Annona montana on Spodoptera frugiperda, Journal Pest Science, 83: 307-310. 2010.

doi: 10.1007/s10340-010-0299-331

[12] Innocent E, Kisanga AC, Gamba N, Kisinza WN, Hassanali A. Effect of Annona formulations on non-target invertebrates and on physicochemical water parameters at semi-field condition, Journal of Entomology and Zoology Studies, 2(3): 214-219, 2014.

http://www.entomoljournal.com/vol2Issue3/pdf/19.1.pdf

[13] Castillo LE, Jiménez JJ, Delgado MA. Secondary metabolites of the Annonaceae, Solanaceae and Meliaceae families used as biological control of insects. Tropical and Subtropical Agroecosystems, 12(3): 445-462, 2010.

http://www.redalyc.org/html/939/93915170004/

[14] Krinski D, Massaroli A, Machado M. Potential insecticide de plantas da familia Annonaceae. Revista Brasileira de Fruticultura, 36(spe1): 225-42, 2014.

doi: 10.1590/S0100-29452014000500027

[15] Azazy AM, Abdelall MFM, El-Sappagh IA, Khalil AEH. Biological control of the onion thrips, Thrips tabaci Lindeman (Thysanoptera: Thripidae), in open fields using Egyptian entomopathogenic nematode isolates, Egyptian Journal of Biological Pest Control, 28(1): 17, 2018.

doi: 10.1186/s41938-017-0025-9

[16] Lebedev G, Abo-Moch F, Gafni G, Ben-Yakir D, Ghanim M. High-level of resistance to spinosad, emamectin benzoate and carbosulfan in populations of Thrips tabaci collected in Israel. Pest Management Science, 69(2): 274-277, 2013.

doi: $10.1002 /$ ps.3385.

[17] Zamar MI, Arce de Hamity MG, Andrade A, Amendola de Olsen A, Hamity V. Efecto de productos no convencionales para el control de Thrips Tabaci (Thysanoptera: Thripidae) en el cultivo de Ajo (Allium sativum) en la quebrada de Humahuaca (Jujuy-Argentina). Idesia (Arica), 25(3): 41-46, 2007.

doi: 10.4067/S0718-34292007000300005

[18] Castro L, Alzate M, Guerrero G. Estudio preliminar de la bioactividad de extractos de semillas de Annona cherimolia de la familia annonaceae. Science and Techology XVI, 1(44): 326-330, 2010.

doi: $10.22517 / 23447214.1859$

[19] Lagarto A, Silva R, Guerra I, Iglesias L. Comparative study of the assay of Artemia salina L. and the estimate of the medium lethal dose (LD50 value) in mice, to determine oral acute toxicity of plant extracts, Phytomedicine, 8(5): 395-400, 2001.

doi: 10.1078/0944-7113-00044 
[20] McLaughlin JL, Rogers LL, Anderson JE. The Use of Biological Assays to Evaluate Botanicals, Drug Information Journal, 32(2): 513-524, 1998.

doi: $10.1177 / 009286159803200223$

[21] Durán A, Onofre V, Aragón A, Rodríguez C, Tapia AM, Lopez-Olguín JF. Técnica de laboratorio para la cría de Thrips tabaci Lindeman (Thysanoptera: Thripidae), Avances en Agroecologia y Ambiente, I: 327-336, 2007.

[22] Herrera-Vásquez JÁ, Barba-Alvarado AA. Identificación de Thrips palmi (Thysanoptera: Thripidae) en cultivos de Cucurbitáceas en Panamá, Agronomia Mesoamericana, 24(1): 47-55, 2013.

doi: $10.15517 / a m . v 24 i 1.9640$

[23] Giraldo AI, Guerrero G, Arrubla JP, Baena LM, Cuervo DP, Gomez M. The effects of Annonaceae and Amaryllidaceae extracts in controlling the Thrips tabaci Lindeman (Thysanoptera: Thripidae), Revista Brasileira de Ciências Agrárias, 15(2): 1-9, 2020.

doi: 10.5039/agraria.v15i2a6933

[24] Magalhães LM, Santos F, Segundo MA, Reis S, Lima JLFC. Rapid microplate highthroughput methodology for assessment of Folin-Ciocalteu reducing capacity, Talanta, 83(2): 441-447. 2010.

doi: $10.1016 /$ j.talanta.2010.09.042

[25] Ortiz J, Marín-Arroyo MR, Noriega-Domínguez MJ, Navarro M, Arozarena I. Color, phenolics, and antioxidant activity of blackberry (Rubus glaucus Benth.), blueberry (Vaccinium floribundum Kunth.), and apple wines from Ecuador, Journal of Food Science, 78(7): 985-993, 2013.

doi: $10.1111 / 1750-3841.12148$

[26] Calderón-Oliver M, Escalona-Buendía HB, Medina-Campos ON, Pedraza-Chaverri J, Pedroza-Islas R, Ponce-Alquicira E. Optimization of the antioxidant and antimicrobial response of the combined effect of nisin and avocado byproducts, LWT - Food Science and Technology, 65: 46-52, 2016.

doi: 10.1016/j.lwt.2015.07.048

[27] Giraldo A, Guerrero G. Rollinia mucosa (Jacq.) Baillon (Annonaceae) active metabolites as alternative biocontrol agents against the lace bug Corythucha gossypii (Fabricius): an insect pest, Universitas Scientarium, 23(1): 21-34, 2018.

doi: 10.11144/javeriana.sc23-1.rmjb

[28] Salas J, Morales G, Mendoza O, Álvarez C, Parra A. biología y hábitos de vida de Thrips tabaci Lindeman Thysanoptera: Thripidae en cebolla Allium cepa L, Agronomia Tropical, 43(3): 173-183, 1993.

http://sian.inia.gob.ve/revistas_ci/Agronomia Tropical/at4334/Arti/salas_j.htm

[29] Vasco C, Ruales J, Kamal-Eldin A. Total phenolic compounds and antioxidant capacities of major fruits from Ecuador, Food Chemistry, 111(4): 816-823, 2008. 
doi: 10.1016/j.foodchem.2008.04.054

[30] Colom OÁ, Neske A, Chahboune N, Zafra-Polo MC, Bardón A. Tucupentol, a novel monotetrahydrofuranic acetogenin from Annona montana, as a potent inhibitor of mitochondrial complex I, Chemistry \& Biodiversity, 6(3): 335-340, 2009.

doi: $10.1002 / \mathrm{cbdv} .200800102$

[31] Liaw C-C, Chang F-R, Chen S-L, Wu C-C, Lee K-H, Wu Y-C. Novel cytotoxic monotetrahydrofuranic Annonaceous acetogenins from Annona montana, Bioorganic \& Medicinal Chemistry, 13(15): 4767-4776, 2005.

doi: 10.1016/j.bmc.2005.05.008

[32] Mullin C a, González-Coloma A, Gutiérrez C, Reina M, Eichenseer H, Hollister B, Chyb S. Antifeedant effects of some novel terpenoids on Chrysomelidae beetles: comparisons with alkaloids on an alkaloid-adapted and nonadapted species, Journal of Chemical Ecology, 23(7): 1851-1866. 1997.

doi: 10.1023/B:JOEC.0000006455.72602.3f

[33] Liaw CC, Chang FR, Wu YC, Wang HK, Nakanishi Y, Bastow KF, Lee KH. Montacin and cis-montacin, two new cytotoxic monotetrahydrofuran annonaceous acetogenins from Annona montana, Journal of Natural Products, 67(11): 1804-1808, 2004.

doi: $10.1021 / \mathrm{np} 030216 \mathrm{p}$

[34] Wang LQ, Zhao WM, Qin GW, Cheng KF, Yang RZ. Four novel annonaceous acetogenins from Annona montana, Natural Product Letters, 14(2): 83-90, 1999.

doi: $10.1080 / 10575639908041214$

[35] Colom OA, Neske A, Popich S, Bardón A. Toxic effects of annonaceous acetogenins from Annona cherimolia (Magnoliales: Annonaceae) on Spodoptera frugiperda (Lepidoptera: Noctuidae), Journal of Pest Science, 80(1): 63-67, 2004.

doi: 10.1007/s10340-006-0149-2

[36] Ansante TF, do Prado Ribeiro L, Bicalho KU, Fernandes JB, das Graças Fernandes da Silva MF, Vieira PC, Vendramim JD. Secondary metabolites from Neotropical Annonaceae: Screening, bioguided fractionation, and toxicity to Spodoptera frugiperda (J.E. Smith) (Lepidoptera: Noctuidae), Industrial Crops and Products, 74: 969-976, 2015.

doi: 10.1016/j.indcrop.2015.05.058

[37] Il-Kwon P, Hoi-Seon L, Sang-Gil L, Ji-Doo P, Young-Joon A. Antifeeding Activity of Isoquinoline Alkaloids Identified in Coptis japonica Roots Against Hyphantria cunea (Lepidoptera: Arctiidae) and Agelastica coerulea (Coleoptera: Galerucinae), Journal of Economic Entomology, 93(2): 331-335, 2000.

doi: 10.1603/0022-0493-93.2.331

[38] Mann RS, Kaufman PE. Natural Product Pesticides: Their Development, Delivery and Use Against Insect Vectors, Mini-Reviews in Organic Chemistry, 9: 185-202, 2012.

doi: $10.2174 / 157019312800604733$ 
[39] Palomino, Lady, García C, Gil J, Rojano B, Durango D. Determinación del contenido de fenoles y evaluación de la actividad antioxidante de propóleos recolectados en el departamento de Antioquia (Colombia), Viate, 16(3): 388-395, 2009.

[40] Fidyasari A, Wulandari S, Sari MI. Secondary metabolite, and antioxidant activity of soursop (Annona montana) fruit extract, International Journal of Technology Science, 1(2): 10-15, 2017.

https://ejournal.itn.ac.id/index.php/ijts/article/view/74

[41] Barreiros ML, De Jesus RA, Barreiros ALBS, Sandes TS, Ramalho SA, Narain N. Evaluation of the antioxidant activity of eight tropical fruits by DPPH method, Acta Horticulturae, 1198: 185-192, 2018.

doi: 10.17660/ActaHortic.2018.1198.29

[42] Kuskoski M, Asuero A, Troncoso A, Mancini-FFilho J, Fett R. Aplicación de diversos métodos químicos para determinar actividad antioxidante en pulpa de frutos, Food Science and Technology, 25(4): 726-732, 2005.

doi: 10.1590/S0101-20612005000400016

[43] Barreca D, Laganà G, Ficarra S, Tellone E, Leuzzi U, Galtieri A, Bellocco E. Evaluation of the antioxidant and cytoprotective properties of the exotic fruit Annona cherimola Mill. (Annonaceae), Food Research International, 44(7): 2302-2310, 2011.

doi: 10.1016/j.foodres.2011.02.031

[44] Baskar R, RajeswaRi V, Sathish T. In vitro antioxidant studies in leaves of Annona species, Indian Journal of Experimental Biology, 45(5): 480-485, 2007.

doi: 10.1021/acs.jpcb.8b07859

[45] Khaliq A, Khan AA, Afzal M, Tahir HM, Raza AM, Khan AM. Field evaluation of selected botanicals and commercial synthetic insecticides against Thrips tabaci Lindeman (Thysanoptera: Thripidae) populations and predators in onion field plots, Crop Protection, 62: $10-15,2014$.

doi: 10.1016/j.cropro.2014.03.019

[46] Satyanarayana P, Singh P. Relative field efficacy of botanicals, bio-pesticides, and synthetic insecticides against thrips (Thrips tabaci Lind) on onion, Journal of Experimental Zoology, 19(1): 191-194, 2016.

http://www.connectjournals.com/jez 


\section{Actividades biológicas de extractos de Annona montana Macfad}

Resumen: Annona montana Macfad es una especie frutal de la familia Annonaceae. En este estudio se investigó el potencial fitoquímico de las semillas de A. montana. Se evaluaron los extractos etanólico y hexánico de las semillas para determinar citotoxicidad y actividad insecticida, contenido fenólico y capacidad antioxidante; esta última, relacionada con los ensayos de actividad de captación de radicales libres (DPPH) y de poder reductor férrico (FRAP). La exposición de Artemia salina a ambos tipos de extractos de semillas reveló su alta toxicidad, con una concentración letal media (LC50) de $<10 \mu \mathrm{g} \mathrm{mL}^{-1}$. La evaluación posterior de la actividad insecticida de $A$. montana contra Thrips tabaci L. reveló que los tratamientos más promisorios se observaron en la concentración de $100 \mathrm{mg} \mathrm{L}^{-1}$ en ambos extractos. El extracto etanólico resultó en una mortalidad de $67.5 \%$ y el hexánico, en una mortalidad de $53.3 \%$. El extracto etanólico de semillas de A. montana mostró el contenido fenólico más alto: $297.38 \mathrm{mg}$ GAE $/ 100 \mathrm{~g}$ de extracto seco, y $192.66 \mathrm{mg}$ TE/ $100 \mathrm{~g}$ y $385.46 \mathrm{mg}$ TE/ $100 \mathrm{~g}$ para DPPH y FRAP, respectivamente. La caracterización química de ambos extractos por cromatografía líquida de alta resolución (HPLC) reveló la presencia de acetogeninas. Los resultados indican que los extractos de A. montana son una fuente promisoria de compuestos con actividad insecticida.

Palabras Clave: Annonaceae; antioxidante; citotoxicidad; DPPH, FRAP, actividad insecticida.

\section{Atividades biológicas de extratos de Annona montana Macfad}

Resumo: Annona montana Macfad é uma espécie de fruta da família Annonaceae. Neste estudo, pesquisamos o potencial fitoquímico de sementes de A. montana. Estratos de sementes em etanol e hexano foram avaliados quanto a sua citotoxicidade, atividade inseticida, conteúdo fenólico e capacidade antioxidante. Este último relacionado a um ensaio de atividade de eliminação de radicais livres (DPPH) e poder redutor férrico (FRAP). Expor Artemia salina aos dois tipos de estratos de semente revelou sua alta toxicidade com uma concentração letal média (LC50) de $<10 \mu \mathrm{g} \mathrm{mL}^{-1}$. Adicionalmente, a atividade inseticida das sementes de A. montana foi avaliada contra Thrips tabaci L. Os tratamentos mais promissórios foram observados a uma concentração de $100 \mathrm{mg} \mathrm{L}^{-1}$ nos dois extratos. O estrato em etanol resultou numa mortalidade de $67.5 \%$ e os estrato em hexano resultou em $53.3 \%$ de mortalidade. O estrato etanólico de semente de A. montana apresentou o maior conteúdo fenólico total: $297.38 \mathrm{mg} \mathrm{GAE} / 100 \mathrm{~g}$ de extrato seco e $192.66 \mathrm{mg}$ TE$/ 100 \mathrm{~g}$ e $385.46 \mathrm{mg}$ TE/ $100 \mathrm{~g}$ para o DPPH e FRAP, respectivamente. A caracterização química dos dois extratos por cromatografia líquida de alta resolução (HPLC) revelou a presencia de acetogeninas. Os resultados obtidos indicam que os extratos de $A$. montana são uma fonte promissória de compostos com atividade inseticida.

Palavras-chave: Annonaceae; antioxidante; citotoxicidade; DPPH, FRAP, atividade inseticida 
Ana Isabel Giraldo-Rivera Industrial Chemist and Mcs in Science Chemistry graduated from Universidad Tecnológica de Pereira, she was student distinguished for her academic performance. She works as research assistant at Oleoquimica Laboratory and professor from the School of Chemistry of the Universidad Tecnológica de Pereira (UTP).

ORCID: 0000-0002-4733-5460

Gloria Edith Guerrero-Álvarez Chemist and $\mathrm{PhD}$ in Science Chemistry from Universidad Nacional Colombia sede Bogotá. She is professor from the School of Chemistry of the Universidad Tecnológica de Pereira (UTP) and Director of the Oleoquimica Laboratory where has oriented several research, projects and thesis of undergraduate students.

ORCID: 0000-0002-0529-5835 